\title{
NICHOLAS OF AUTRECOURT: A FORERUNNER OF PARACONSISTENT LOGICS
}

\author{
Arturo Tozzi \\ Center for Nonlinear Science, Department of Physics, University of North Texas, Denton, Texas, \\ USA \\ ASL Napoli 2 Nord, Distretto 45, Caivano, Naples, Italy \\ tozziarturo@libero.it \\ arturo.tozzi@alsnapoli2nord.it
}

We suggest that the $14^{\text {th }}$ century scholar Nicholas of Autrecourt can be regarded as a precursor of the paraconsistent logics developed around 1950. We show how the Sorbonne licentiatus in theology provided in his few extant writings a refutation of both the principle of explosion and the law of non-contradiction, in accordance with the tenets of paraconsistent logics. This paves the way to the most advanced theories of truth in natural language and quantum dynamics.

Keywords: non-classical logic; scholasticism; theology; epistemology; condemnation.

Paraconsistent logics (henceforward PCLs), first put forward in 1910-1929 by the Russians Vasil'év and Oreov, were formalized around the 50s by the Polish Jaśkowski (1948) and the Brazilian da Costa (1974). Suggesting that not every contradiction entails arbitrary absurdities, PCLs reject two tenets of the classical aristotelian logic: the principle of explosion (henceforward PEX) and the law of noncontradiction (henceforward LNC).

The principle of explosion (PEX) asserts that ex falso quodlibet, i.e., from falsehood -or from contradiction- anything follows). PEX states that:

$$
\mathrm{p} \wedge \neg \mathrm{p} \rightarrow \mathrm{q}
$$

i.e., for any statements $p$ and $q$, if $p$ and not-p are both true, then it logically follows that $q$ is true. Once a contradiction has been asserted, both a positive statement and its own negation can be proven true. The inference from $p$ and $\neg p$ to an arbitrary conclusion leads to inconsistencies in formal axiomatic systems, since it makes it impossible to distinguish truth from falsehood. To avoid the dangers of meaningless statements implicit in PEX, the law of noncontradiction (LNC) comes to the rescue:

$$
\neg(\mathrm{p} \wedge \neg \mathrm{p})
$$

Since contradictories cannot be simultaneously true, LNC removes the inconsistency from the beginning and neutralize PEX.

PCLs, together with other non-classical logics such as relevance and minimal logic (Johansson 1973), suggest that the classical ex falso quodlibet is incorrect (Priest and Routley, 1989), since the inference from $p$ and $\neg p$ to an arbitrary conclusion does not hold (Varzi 2000). A logic is paraconsistent iff it is not the case for all sentences $p, q$ that $p, \neg p \vdash q$. This means that we cannot be certain of the truth of any proposition which is irreducible to PEX (Copleston 1974). 
Apart from the logical treatment tackled in the 12th-century by the French Parvipontians Adam Balsham and William of Soissons (Priest 2011), PEX has been accepted as self-evident throughout the centuries. We show that the critique to PEX (and also to LNC) put forward by PCLs has been anticipated in writings dating back to the first half of the $14^{\text {th }}$ century. The 50year-old Nicholas of Autrecourt, a Master of Arts in the Parisian arts faculty and baccalaureus and licentiatus in theology, was condemned in 1347 by the papal court in Avignon after allegations of false teaching. Around 60 articles of either "false, or erroneous, suspect, presumptuous, dangerous, or heretic" propositions were collected and publicly recanted in Avignone and Paris (Kaluza 1995).

\section{CRITIQUE TO THE PRINCIPLE OF EXPLOSION}

Here we focus on Autrecourt's condemned articles concerning LNC, that he calls the primum principium. The Latin articles reproduced here are numbered according to the Chartolarium Universitatis Parisiensis (Deniflis and Chatelain, 1891):

Item, dixi, proh dolor, in primo principio $^{3}$ quando legi Sententias et in epistola secunda et sexta, quas scripsi contra Bernardum', quod ex eo quod una res est, non potest evidenter evidentia deducta ex primo principio inferri, quod alia res sit (5). Falsam et revocandam.

Item, dixi in locis predictis quod ex eo, quod una res est, non potest evidenter inferri quod alia res non sit $(6) .-$ Falsam et revocandam.

Item, dixi in locis predictis quod ex eo, quod una res non est, non potest evidenter evidentia deducta ex primo principio inferri. quod alia res non sit (8). - Falsam et revocandam.

Item, dixi locis predictis quod ex eo, quod una res non est, non potest evidenter inferri, quod alia res sit (7). - Falsam et revocandam, quanquam aliqui dicant eam veram esse.

Here is an approximate translations:

Starting from LNC, it follows that:

- From the fact that one thing is, it cannot be inferred the fact that another thing is (5)

- From the fact that one thing is, it cannot be inferred that another thing is not (6)

- From the fact that one thing is not, it cannot be inferred that another thing is (7)

- From the fact that one thing is not, it cannot be inferred that another thing is not (8)"

Therefore, Autrecourt suggests that the following logical propositions cannot be inferred from LNC:

$$
\begin{gathered}
p \rightarrow q \\
p \rightarrow \neg q \\
\neg p \rightarrow \neg q \\
\neg p \rightarrow q
\end{gathered}
$$

Summarizing, Autrecourt rules that:

$$
\neg(\mathrm{p} \vee \neg \mathrm{p}) \rightarrow \neg(\mathrm{q} \vee \neg \mathrm{q})
$$


Consequently,

$$
\neg(\mathrm{p} \wedge \neg \mathrm{p}) \rightarrow \neg(\mathrm{q} \vee \neg \mathrm{q})
$$

Therefore, since $\mathrm{p} \wedge \neg \mathrm{p} \rightarrow \mathrm{q}$ is false, Autrecourt does reject PEX as the modern PCLS do (Fitch 2013).

The unfeasibility of $\mathrm{p} \wedge \neg \mathrm{p} \rightarrow \mathrm{q}$ is frequently observed also in natural language, e.g., when two men hold opposite conclusions (Treatise, O'Donnell 1936, pg. 236, Chapter: an omne illud quod apparet sit):

Et hic dicendum est quod tenentibus oppositas conclusiones aliquid est utrique clarum, sed non in illo vel in illis contradicunt, sed interdum utuntur uno pro alio ut supra dicebatur, ${ }^{175}$ verbi gratia, et hoc vidi frequenter accidere de facto. Aliquis loquitur; sunt aliqui qui audiunt; interdum unus dicit: ille dixit hoc, et in veritate illud non dixit; et alius dicit: immo dixit hoc. Et pone quod sic sit, tunc isti dicuntur sibi contradicere, et tamen secundum veritatem opposita non veniunt in evidentia apud intellectum eorum; nam primo qui dicit me dixisse aliquid quod non dixi, non est sibi evidens quod illud dixerim, sed est sibi evidens quod me loquente conceptus illius rei venit ad intellectum ipsius, et forsan vel ex modo meo lo/quendi vel quia expressum a me erat propinquum illi in quod incidit; etiam est sibi evidens quod ego aliquid dixi et quod movi labia, sed non est sibi evidens quod ego dixerim illud; utitur ergo uno pro alio. Sed dices adhuc: secundum istum modum respondendi sequeretur quod intellectus de nullo specialiter posset dicere se esse certum, licet de aliquo posset in genere; nam secundum te intellectus potest uti uno pro alio et ita omnino judicabit aliquid esse clarum, et tamen illud non erit sibi clarum, sed quoddam aliud de quo non judicabit. Et si dicas quod aliquis habebit certitudinem, sed carebit omni medio per quod probare posset sibi vel alii se esse certum, quia ille gradus cognitionis, cum quo non potest stare oppositum, non est sic determinatus ut possit sciri, sequitur: hic est, hic non est.

Sometimes one says: "I said this", while the other says: "no. I said that", even though something is clear to both. Everything which appears to be true is true according to the two contenders, even at the risk to predicate the truth and the falsity of the same thing in the logical discourse. People taking part in the discussion may disagree while being (self-) consistent, using some vague terms either purposefully or unintentionally (Ciuciura 2013). Conclusions are not really demonstrated since the opposite conclusions can be drawn from the evidence of each one of the contenders. This approach is very similar to what suggested by the PCLs' non-adjunctive discursive logic: "from the fact that a thesis $\mathrm{P}$ and a thesis $\mathrm{Q}$ have been advanced in a discourse it does not follow that the thesis PVQ has been advanced, because it may happen that $\mathrm{P}$ and $\mathrm{Q}$ have been advanced by different persons" (Jaśkowski 1999).

In conclusion, Autrecourt's account is in touch with paraconsistent logics: they both aim to remove PEX. 


\section{WHEN THE LAW OF NONCONTRADICTION FAILS}

The logical and epistemological strength of LNC in Autrecourt's writings is matter of controversy. It has been suggested that he bears a dual interpretation of the certitude provided by LNC (Groarke 1984). On the one hand, Autrecourt holds the conventional, scholastic medieval view that LNC stands for the foremost principle ensuring firm ground upon which to build the truth. For example, in the second letter to Bernard, Autrecourt writes that there is no other certitude but the certitude of LNC, except for the certitudes of faith (De Rijk 1994). He asserts that every syllogism can be reduced to the truth of LNC trough immediate or mediate operations. On the other hand, in other places Autrecourt raises questions about the steadiness of his own belief in LNC. The last chapters of the Tractatus (conceivably written later) appear to somewhat deny the absolute certitude previously guaranteed by LNC. The most contentious paragraphs (O'Donnell 1939, pg. 237, chapter: an omne illud quod apparet sit) are reproduced here:

Octava conclusio est quod non omnes propositiones possunt ostendi esse evidentes per primum principium; nam cum primo principio oportet assumere aliquid quod contineat conclusionem in actu; minor non, quemadmodum major et principium primum, videlicet in potentia.

Nona conclusio est, quod aliquis posset per consuetudinem aut alias resilire, ut non assentiret indubitanter ei, quod est primum principium esse verum utpote, si sic nutriretur, ut sibi diceretur, quod est aliquod agens omnipotens, quod potest facere contrarium et quod non debet ipsum movere evidentia, quia oppositum potest stare cum ea ut declararetur in multis.

Decima conclusio est quod non posset non assentire quin esset sibi clarum et evidens.

Here an objection is raised, put forward in Giles' Letter to Nicholas too (De Rijk 1994): the fact that God can make miracles seems to deny the existence of LNC. Indeed, God can annihilate every proposition by miracle, and, if He should do so, LNC would not be valid, since it would not even exist. This means that the possibility to distinguish, e.g., between the propositions "God exists" and "God does not exist" fades away. If contradictories signify the same, the firmness of LNC is undermined beyond repair. Elsewhere in the Treatise Autrecourt suggests that the only thing which guarantees the certitude of the first principles is our firm belief that we know them clearly and evidently.

Another highly controversial paragraph of the Tractatus (O'Donnel JR 1939, pg 237, Chapter: an omne illud quod apparet sit) states:

Sexta conclusio est quod nulla conclusio potest probari esse vera nisi per medium evidentiae; hoc est quod probetur esse evidens per propositiones evidentes.

According to Kennedy's influential translation (Kennedy et al., 1971):

"The sixth conclusion is that there is no conclusion that can be proven true unless by means of evidence, that is, unless it be proven evident by evident propositions".

This translation emphasizes the main role of PNC in gnoseological issues. However, Kennedy's translation is wrong, since per medium does not mean "by means". The true sense of the test is different:

"the sixth conclusion is that no conclusion can be proven true if not by (considering) the evidence of the middle (term of the proposition), i.e., what is proven to be evident through evident propositions".

This latter translation runs counter PNC as the tenet of firm belief. In Autrecourt's opinion, the knowledge of appearances cannot rely on LNC, since what is known through LNC is analytic and devoid of factual information (Beuchot, 2005). 
In touch with the critique to PNC, it is noteworthy that one among PCLs, i.e, the relevance logic, states that antecedent and consequent of implications must be relevantly related. It is remarkable that this correlation is explicitly required by Autrecourt too, who states that the antecedent and the subsequent must share their contents. The consequent cannot be inferred from a doubtful antecedent, since antecedent and consequent obey the principle of identity and must be identical. According to Autrecourt, a priori demonstrations hold just when the identity $A=A$ occurs between the consequent and the antecedent (dal Pra 1952; Maccagnolo 1953). In Autrecourt the cognitive borders between logical and psychological approaches are rather fuzzy. His duality lies in the fact that at times he stresses empiricism, at another time Revelation. Here we provide a few examples. In a letter to Giles, Autrecourt writes that it is unclear whether the consequent is equal to the antecedent, since it is not discernible whether a perceived thing is simple and indivisible (De Rijk 1994). Only God comprehends all the things in a single, simple apprehension. The strongest way to provide a bridge between mental contents and their supposed noumenal correlates is to build a probability, though probable in the mere sense of being of worthier assent than its contradictory opposite (McDermott 1973).

In conclusion, Autrecourt's account is in touch with paraconsistent logics: they both aim to remove not just PEX, but also LNC.

\section{CONCLUSIONS}

We showed how and why Nicholas of Autrecourt can be considered to have pioneered the modern paraconsistent logics.

In the sequel, we suggest novel lines of research involving Autrecourt and PCLs. Autrecourt states in the Treatise that the ultimate reason why the evident truths (including LNC) are to be accepted is that they please our minds, since a being is nobler that another if naturally pleases men more (Kennedy et al., 1971). In touch with Aristotle, the optimistic concept of cosmic goodness is the pivotal point of Autrecourt's system. Since the universe has complete goodness, falsehood is the evil of intellect. The intellect is not made for being pleased with the false, so that it can be stated that "what appears is, what is evident is true" (McDermott 1973). The concept of cosmic goodness recalls the modern notion of the antropic principle (Dicke 1961), which states that the scientific scrutiny of the Universe would not even be possible if the laws of the universe had been incompatible with the development of life. Since humans are still here, this means that the evolution did not let our senses to believe to false cues, otherwise we could not have survived. This takes us in the logical world of PCLs, where our intellect makes an effort to grab not just the being, but also the non-being (Maccagnolo 1953). In touch with Autrecourt's cosmic goodness, PCLs hold that no true theory would ever contain inconsistencies. In practice, PCLs (and the gnoseological belief in truth provided by evolution) allow damage control to restore contradictions when information systems generate unavoidable errors.

A further connection can be found among Autrecourt, PCLs and quantum mechanics (Brown 1993). Autrecourt writes in the Tractatus that two points can touch with each retaining its own different position. This apparently weird statement is in touch with the quantum concept of bosons' superposition. Bosons are not subject to the Pauli exclusion principle: any number of identical bosons can occupy the same quantum state. Further, Autrecourt states in the Condemnations that a transition occurs from one state to the contradictory one in the absence of a real intrinsic change of any of the terms. Connectives such as " $\neg$ " do not mean anything since they are syncategorematic terms lacking denotation and ontological status (Thijssen 1990). In touch with Ockham, Autecourt seems to support the thesis that we have no knowledge of things outside the word, but only of terms: God and creatures become nothing. In accordance with this approach, recent approaches interpret quantum mechanics as a reference-frame theory 
pertaining to observer-dependent relational properties (see, e.g., Yang 2018). Amazingly, these rather extreme relational formulations of quantum mechanics have been experimentally supported by recent studies (The BIG Bell Test Collaboration 2018). Their results, in touch with PCLs and Autrecourt's Ockhamism, seem to contradict local realism, suggesting that the properties of the physical world are dependent from the observer.

\section{REFERENCES}

1) Autrecourt, Nicholas of. About 1340. The Universal Treatise. Marquette University Press, Milwaukee, Wisconsin, 1971.

2) Autrecourt N. 1939. "Exigit ordo" /Universal Treatise. Ed. O'Donnell JR, "Nicholas of Autrecourt", Mediaeval Studies 1: 179-280.

3) Beuchot M. 2005. Nicholas of Autrecourt. In: A Companion to Philosophy in the Middle Ages. Eds: Gracia JJE, Noone TB. ISBN:9780631216728. DOI:10.1002/9780470996669.

4) Brown B. 1993. Old Quantum Theory: A Paraconsistent Approach. Proceedings of the Philosophy of Science Association 2: 397-441.

5) Ciuciura J. 2013. Non-adjunctive discursive logic. Bulletin of the Section of Logic 42(3).

6) Copleston FC. 1974. The Logical Empiricism of Nicholas of Autrecourt. Proceedings of the Aristotelian Society. New Series, Vol. 74 (1973 - 1974), pp. 249-262.

7) da Costa, Newton C. A. 1974. On the Theory of Inconsistent Formal Systems. Notre Dame Journal of Formal Logic 15, pp. 497-510.

8) dal Pra M. 1952. La fondazione dell' empirismo e le sue aporie nel pensiero di nicola di Nicola di Autrecourt. Rivista Critica di Storia della Filosofia. 7(5):384-402

9) De Rijk LM. 1994. Nicholas of Autrecourt: his correspondence with master Giles and Bernard of Arezzo. Brill Academic Pub, Leiden, New York, Koln. ISBN-10: 9004099883.

10) Deniflis H, Chatelain A. 1891. Chartolarium Universitatis Parisiensis. Tomus II, Sectio Prior. Parisiis, ex typis fratrum Delalain.

11) Dicke RH. 1961. Dirac's Cosmology and Mach's Principle. Nature. 192 (4801): 440-441. doi:10.1038/192440a0.

12) Fitch R. 2013. Nicholas of Autrecourt and the mastery of reason. DT 116,3: 168-189.

13) Groarke L. 1984. On Nicholas of Autrecourt and the Law of Non-Contradiction. Dialogue: Canadian Philosophical Review. Volume 23, Issue 1, 129-134. DOI: 10.1017/S0012217300019181.

14) Jaśkowski, S. 1948. Rachunek zdań dla systemów dedukcyjnych sprzecznych. Studia Societatis Scientiarum Torunensi (Sectio A), 1(5): 55-77.

15) Jaśkowski S. 1999. Log. Log. Philos. 7, 35-56 (Zbl 1013.03004), p. 49.

16) Johansson I. 1937. Der Minimalkalkül, ein reduzierter intuitionistischer Formalismus. Compositio Mathematica. 4: 119-136.

17) Kaluza Z. 1995. Nicolas d'Autrecourt. Ami de la vérité, in Histoire littéraire de la France, 42(1), Paris.

18) Kennedy LA, Arnold RE, Millward AE. 1971. The Universal Treatise of Nicholas of Autrecourt. Marquette University press, Milwaukee, Wisconsin

19) Maccagnolo E. 1953. Metafisica E Gnoseologia In Nicolò D'Autrecourt. Rivista di Filosofia Neo-Scolastica. Vol. 45, No. 1, pp. 36-53.

20) McDermott C. 1973. Direct Sensory Awareness: A Tibetan View and a Medieval Counterpart. Philosophy East and West Vol. 23, No. 3 (1973) pp. 343-360.

21) O'Donnel JR 1939. Nicholas of Autrecourt Medieval studies, vol. 1. Pontifical Institute of Medieval Studies, Toronto, Canada.

22) O'Donnell JR. 1942. The Philosophy of Nicholas of Autrecourt and his Appraisal of Aristotle. Mediaeval Studies, Pages: pp. 97-125. https://doi.org/10.1484/J.MS.2.306538 
23) Priest G, Routley R. 1989. Applications of Paraconsistent Logic. in Priest, Routley and Norman. Munich: Philosophia Verlag.

24) Priest G. 2011. What's so bad about contradictions? In: Priest, Beall and Armour-Garb, The Law of Non-Contradiction. Clarendon Press, Oxford.

25) The BIG Bell Test Collaboration. Challenging local realism with human choices. Nature 2018, 557, 212-216.

26) Thijssen JMMH. 1990. The "semantic" articles of Autrecourtss condemnation. New proposals for an interpretation of the articles 1, 30, 31, 35, 57 and 58. Archives d'histoire doctrinale et littéraire du Moyen Age. Vol. 57 (1990), pp. 155-175 (21 pages). Librairie Philosophique J. Vrin. https:// www.jstor.org/stable/44403829.

27) Thijssen JMMH. 1990. Once again the Ockhamist Statutes of 1339 and 1340: Some new perspectives. Vivarium. Vol. 28, No. 2 (1990), pp. 136-167.

28) Varzi, A. 2000. Supervaluationism and Paraconsistency. in D. Batens, C. Mortensen, G. Priest and J-P. Van Bendegem, eds., Frontiers of Paraconsistent Logic (Baldock: Research Studies Press), pp. 279-97.

29) Yang, J.M. A Relational Formulation of Quantum Mechanics. Sci. Rep.2018, 8, 13305. 